Geological Society, London, Special Publications

Exhumation of the Sierra de Cameros (Iberian Range, Spain): constraints from low-temperature thermochronology

P. Del Río, L. Barbero and F. M. Stuart

Geological Society, London, Special Publications 2009; v. 324; p. 153-166 doi:10.1144/SP324.12

Email alerting service

Permission request

Subscribe click here to receive free email alerts when new articles cite this article

click here to seek permission to re-use all or part of this article

click here to subscribe to Geological Society, London, Special Publications or the Lyell Collection

Notes

Downloaded by on 28 September 2009 


\title{
Exhumation of the Sierra de Cameros (Iberian Range, Spain): constraints from low-temperature thermochronology
}

\author{
P. DEL RÍO ${ }^{1 *}$, L. BARBERO ${ }^{1} \&$ F. M. STUART ${ }^{2}$ \\ ${ }^{1}$ Departamento de Geología, Universidad de Cádiz, 11510 Puerto Real, Cádiz, Spain \\ ${ }^{2}$ Isotope Geosciences Unit, Scottish Universities Environmental Research Centre, \\ Rankine Avenue, Technology Park, East Kilbride G75 OQF, UK \\ *Corresponding author (e-mail: pedro.bermejo@uca.es)
}

\begin{abstract}
We present new fission-track and (U-Th)/He data from apatite and zircon in order to reconstruct the exhumation of the Sierra de Cameros, in the northwestern part of Iberian Range, Spain. Zircon fission-track ages from samples from the depocentre of the basin were reset during the metamorphic peak at approximately $100 \mathrm{Ma}$. Detrital apatites from the uppermost sediments retain fission-track age information that is older than the sediment deposition age, indicating that these rocks have not exceeded $110{ }^{\circ} \mathrm{C}$. Apatites from deeper in the stratigraphic sequence of the central part of the basin have fission-track ages of around $40 \mathrm{Ma}$, significantly younger than the stratigraphic age, recording the time of cooling after peak metamorphic conditions. Apatite (U-Th)/He ages in samples from these sediments are 31-40 Ma and record the last period of cooling during Alpine compression. The modelled thermal history derived from the uppermost sediments indicates that the thermal pulse associated with peak metamorphism was rapid, and that the region has cooled continuously to the present. The estimated palaeogeothermal gradient is around $86^{\circ} \mathrm{C} \mathrm{km}^{-1}$ and supports a tectonic model with a thick sedimentary fill $(c .8 \mathrm{~km})$ and explains the origin of the low-grade metamorphism observed in the oldest sediments.
\end{abstract}

Convergence of the Eurasian and Iberian plates during the Palaeogene-early Miocene led to the formation of the Pyrenees in the northern Iberian margin. The Iberian Range, located to the south of the Pyrenees, is an intraplate mountain chain that formed as a result of migration of compressional deformation towards the inner part of the Iberian microplate during Alpine collision. The Cameros Basin, located in the northwestern most part of the Iberian Chain (Fig. 1), represents a synrift sequence formed prior to the Alpine convergence during the Upper Jurassic-Mid Cretaceous extensional period. It was inverted during the subsequent Alpine shortening, either by the reactivation of the synrift normal faults or on newly formed faults and thrust (Casas-Sainz \& Gil-Imaz 1998).

The stratigraphy, mineralogy, metamorphism and structure of the Sierra de Cameros have been studied for several decades (e.g. Tischer 1966; Mas et al. 1993; Casas-Sainz \& Gil-Imaz 1998; Mata et al. 2001). However, the timing and mechanism of the basin inversion, the origin of the greenschist-facies metamorphism of sediments in the deepest part of the basin and the geometry of the sedimentary filling remain unclear. Three tectonic models have been proposed to explain the formation of the Cameros Basin and the geometry of the synrift deposits.
In the first model Guiraud (1983) and Guiraud \& Séguret (1984) proposed an east-west-striking, south-dipping normal fault in the basement as the structure responsible for the formation of a syncline basin. The sedimentary infilling of this basin progressively onlapped the structure as the depocentre migrated northwards (Fig. 2a). In this model the total thickness of the sedimentary fill would not exceed $5 \mathrm{~km}$. During the Tertiary the basin was inverted, with the normal faults being reactivated as reverse faults.

In a second model Mas et al. (1993) and Guimerà et al. (1995) (Fig. 2b) interpreted the Cameros Basin as a sag basin that formed on a ramp of an extensional, subhorizontal fault located several kilometres deep in the Variscan basement. The sedimentary units that fill the basin decrease in thickness towards the southern border and onlap to the north on the Jurassic, prerift deposits. The depocentres are located on the normal fault ramp and migrated progressively towards the north. Again, the maximum vertical thickness reached by the sedimentary fill would be about $5 \mathrm{~km}$. Tectonic inversion of the basin was caused by a newly formed thrust developed along the northern border, and a thrust system to the south. In these two models the origin of low-grade metamorphism remains unclear and some authors claim for a hydrothermal origin (e.g. Casquet et al. 1992). 

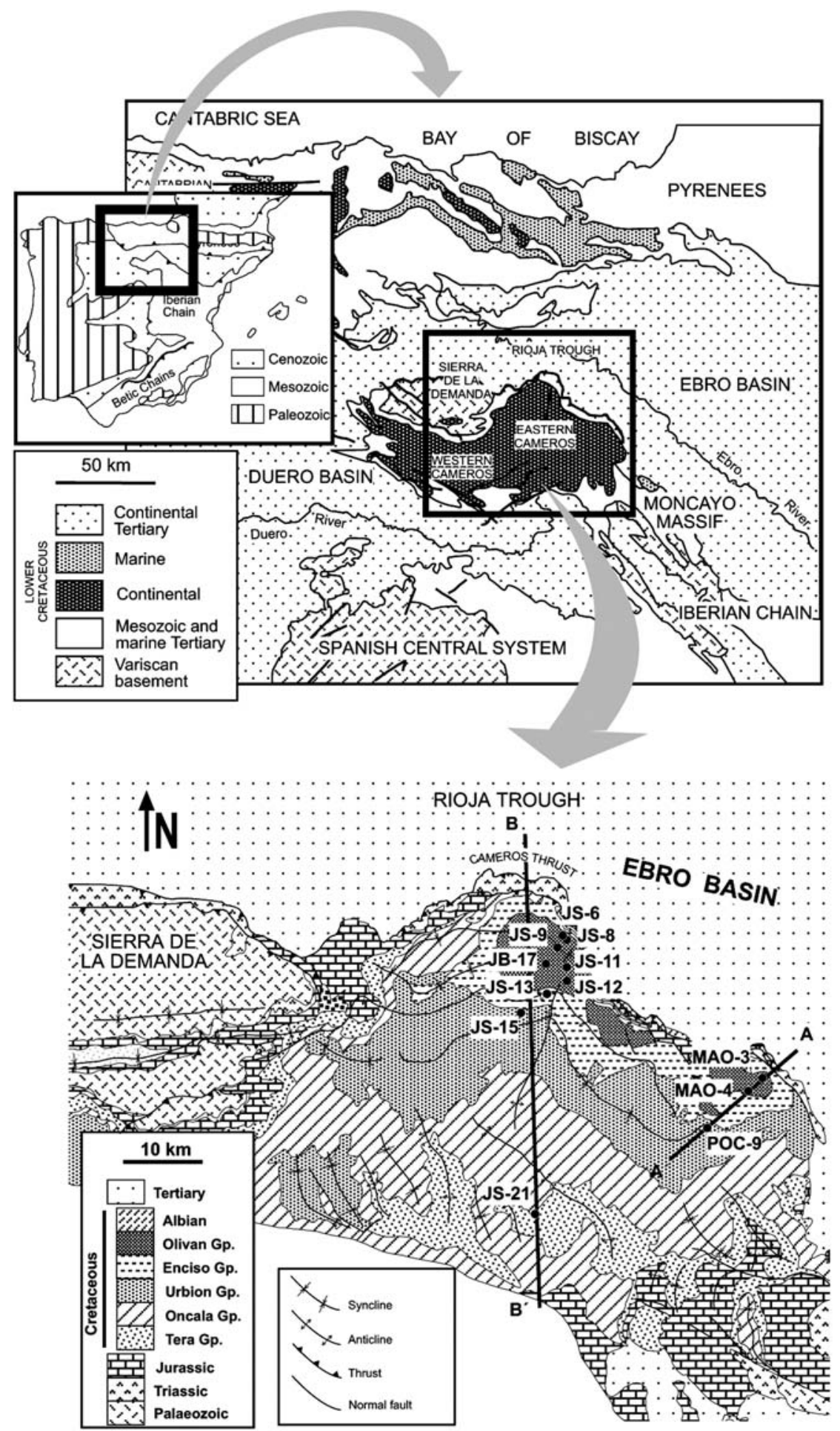

Fig. 1. Schematic geological map of the Sierra de Cameros showing the location of the study area within the context of the Iberian plate and the locations of cross-sections and samples for this study. 


\section{S}

(a)

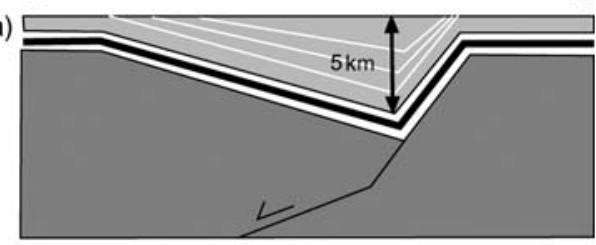

(b)

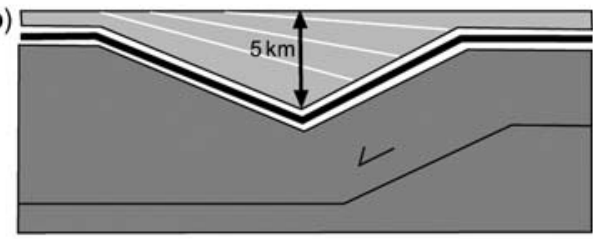

(c)
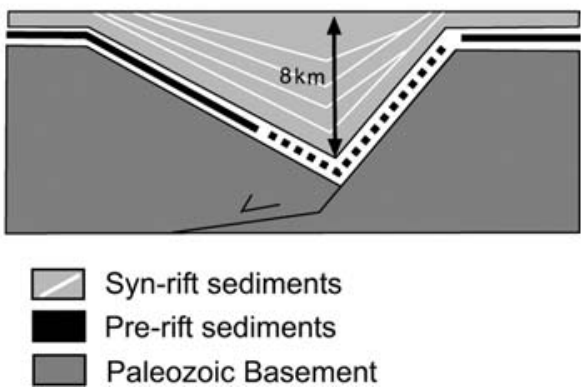

\section{Syn-rift sediments}

Pre-rift sediments

Paleozoic Basement

Fig. 2. Summary of the tectonic models proposed to explain the Cameros Basin evolution (modified after Gil-Imaz et al. 2002). (a) Synsedimentary synclinal model proposed by Guiraud (1983) and Guiraud \& Séguret (1984), with a maximum vertical thickness of about 5 km. (b) Sag-basin model after Mas et al. (1993) and Guimerá et al. (1995) in which the units onlap onto the prerift sequence; a maximum vertical thickness of about $5 \mathrm{~km}$ is reached in this model. (c) Synsedimentary synclinal model proposed by Casas-Sainz \& Gil-Imaz (1998), with vertical stacking of the units reaching a maximum vertical thickness of about $8 \mathrm{~km}$.

Casas-Sainz \& Gil-Imaz (1998) proposed an alternative model in which the basin exhibits a halfgraben geometry controlled by a listric fault developed along previous Variscan structures. This fault does not extend beyond the limits of the basin, and the units stack vertically and decrease in thickness towards the basin margins (Fig. 2c). The maximum vertical thickness reached by the sedimentary fill according to this model was $8 \mathrm{~km}$. During the Tertiary basin inversion the Upper Triassic sediments (Keuper facies) were the detachment level for thrusts involving the Mesozoic cover. This model can satisfactorily explain the origin of low-grade metamorphism in the deep basin mainly as a consequence of burial. The interpretation of the magnetic fabric of rocks (ASM: Gil-Imaz et al.
2000), and fluid inclusions in quartz and calcite filling extensional cracks (Mata et al. 2001) also support this hypothesis.

The Sierra de Cameros shows several features that make it an interesting area for the study of the evolution of intraplate rifting process and far-field effect of the plate boundaries. These include: (1) a well-preserved, thick synrift sedimentary sequence; (2) a unique low-grade metamorphic event and several folding stages that did not appear in other parts of the Iberian Chain; and (3) the presence of thick, well-preserved foreland basin deposits (Ebro Basin) in which it is possible to study the evolution of the eroded part of the Sierra de Cameros.

The application of low-temperature thermochronometers such as fission track and (U-Th)/ He to detrital minerals provides a unique tool to better understand the thermal history of the Sierra de Cameros and, consequently, its geological evolution. This is facilitated by the presence of detrital apatite and zircon crystals in the detrital rocks of the sedimentary sequence of the Cameros Basin. The combination of two low-temperature thermochronological methods allows for new constraints on the palaeogeothermal gradients to be placed, which in turn can be compared to previous data from other independent techniques.

\section{Geological framework}

The Sierra de Cameros forms the main part of the northwestern sector of the Iberian Range. It is bordered by two continental basins, the Ebro and Duero basins to the north and south respectively, and by two Paleozoic massifs, the Sierra de la Demanda to the west and the Moncayo Massif to the east (Fig. 1). Sediments of the Sierra de Cameros were deposited in a Mesozoic basin that formed as a consequence of northward propagation of rifting related to the progressive opening of the North Atlantic Ocean and the Bay of Biscay. Transtensional rifting of the Bay of Biscay resulted in the progressive destruction of the Middle-Late Jurassic carbonate platforms and the development of a new extensional system in the Iberian Range (Mas et al. 2002). The basin exhibited a half-graben-like geometry that was controlled by a system of extensional listric faults with NW-SE strikes that were developed on earlier Variscan structures. The synrift stratigraphic sequence spans from Upper Jurassic (Tithonian-Berriasian) to the upper-lower Cretaceous boundary (Albian-Cenomanian) (Mas et al. 1994; Muñoz et al. 1997). Depositional sequences are classically divided into five lithostratigraphic groups: the Tera, Oncala, Urbión, Enciso and Oliván groups (Tischer 1966). Sediments are largely fluvial sandstones, lutites and conglomerates (Tera, Urbión and Oliván groups), and lacustrine 
carbonates with siliciclastic influence (Oncala and Enciso groups). The clastic sequences are characterized by compositional immaturity (arkoses are abundant) characteristic of proximal facies. The geochemistry of the detrital sediments reveals an acid-igneous or metamorphic source rock (Mata et al. 2000). The sediments may have been sourced in areas close to the Spanish Central System, which is dominated by acid granites and orthogneisses. This is consistent with the palaeo-current directions (Tischer 1966) and the compositional immaturity of the sediments. Depositional ages used in the present work are based on Charophyceae biozones (Schudack 1987), pollen analysis (Martín i Closas 1989) and correlations made by Mas et al. (1993), which give depositional times for the Cameros Basin as follows: lower Albian for the Oliván group; Aptian for the Enciso group; BarremianValanginian for the Urbión group; Berriasian for the Oncala group; and Tithonian for the Tera group.

The presence of chloritoid in the deepest sediments cropping out at present indicates that the region underwent a low-grade metamorphism that peaked of approximately at $326-350{ }^{\circ} \mathrm{C}$ and $1 \mathrm{~kb}$ (Casquet et al. 1992; Mata et al. 2001). Ar-Ar and $\mathrm{K}-\mathrm{Ar}$ ages for peak temperatures are approximately $100 \mathrm{Ma}$ (Goldberg et al. 1988; Casquet et al. 1992). During the Tertiary the basin underwent tectonic inversion related to Alpine compression that produced folding and exhumation of the whole Mesozoic basin The Cameros Basin sediments were thrusted $25-30 \mathrm{~km}$ north along the Cameros thrust over the Tertiary molasse of the Ebro Basin (Guimerà et al. 1995; Casas-Sainz \& Gil-Imaz 1998). During the Palaeocene and Eocene, the Sierra de Cameros was the source area for the detrital sediments that were deposited in the Ebro Basin, in particular for its westernmost part (the Rioja Trough) where they reach a maximum thickness of $5 \mathrm{~km}$ (Muñoz-Jiménez \& Casas-Sainz 1997).

\section{Results}

Fission-track results are shown in Table 1. Radial plots of zircon fission-track (ZFT) ages of the two samples from profile $\mathrm{A}-\mathrm{A}^{\prime}$ are displayed in Figure 3. Zircons from sample MAO-3 from the Oliván group have two age populations that are considerably older than the sediment stratigraphic age (Lower Albian). Zircons from POC-9 (Urbión group) yield a single fission-track age population of about $85 \mathrm{Ma}$. This is considerably younger than the sediment deposition age (ValanginianBarremian).

Apatite fission-track (AFT) data have been obtained in three samples along the profile $\mathrm{A}-\mathrm{A}^{\prime}$ (Fig. 3). Sample MAO-3 (Oliván) shows three age populations: $60.9 \pm 2.9 \mathrm{Ma}(\mathrm{P} 1), 80.0 \pm 4.1 \mathrm{Ma}$ $(\mathrm{P} 2)$ and $122.9 \pm 15.5 \mathrm{Ma}(\mathrm{P} 3)$. Mean track length associated with the $\mathrm{P} 1$ and $\mathrm{P} 2$ age populations are $12.8 \pm 2.2$ and $11.7 \pm 2.4 \mu \mathrm{m}$, respectively, showing in both cases a negatively skewed distribution (Fig. 4). $D_{\text {par }}$ of the P1 and P2 populations have average values of $1.38 \pm 0.14$ and $1.38 \pm 0.13 \mu \mathrm{m}$, respectively. Fluorine (1.321.49 apfu (atoms per formula unit)) and chlorine (0.02-0.03 apfu) contents show a negative correlation with the $D_{\text {par }}$ values (Fig. 5). Sample MAO-4 (lower part of the Oliván Group) shows two age populations of $54.3 \pm 2.4 \mathrm{Ma}(\mathrm{P} 1)$ and $69.8 \pm 5.6 \mathrm{Ma}(\mathrm{P} 2)$ that are younger than its stratigraphic age, and a third population of $127.3 \pm 24.7 \mathrm{Ma}(\mathrm{P} 3)$ that is older than its stratigraphic age. $\mathrm{P} 1$ and $\mathrm{P} 2$ age populations have mean track lengths of $11.3 \pm 2.3$ and $11.6 \pm 2.2 \mu \mathrm{m}$, respectively, showing in both cases a negatively skewed distribution (Fig. 4). Average $D_{\text {par }}$ measurements are $2.2 \pm 0.3 \mu \mathrm{m}$ for P1, $2.1 \pm 0.3 \mu \mathrm{m}$ for $\mathrm{P} 2$ and $2.1 \pm 0.3 \mu \mathrm{m}$ for P3. Fluorine and chlorine contents are 1.26-1.41 and 0.02-0.03 apfu, respectively, and show a negative correlation with the measured $D_{\text {par }}$ (Fig. 5). Finally, sample POC-9 exhibits a single AFT age of approximately $48.3 \pm 4.1 \mathrm{Ma}$.

AFT data from nine sandstone samples along the profile $\mathrm{B}-\mathrm{B}^{\prime}$ are shown in Figure 1. Most samples have several age populations, most of them younger than the depositional age (see radial plots in Fig. 6). Sample JS-6 (Oliván) has an age population of $123.2 \pm 14.9 \mathrm{Ma}$, which is older than the depositional age (Lower Albian), but the other two components are younger. Apatites from samples JS-9 and JS-11, both from the middle part of the Oliván group, yield a single age population of $55.6 \pm 3.2$ and $34.5 \pm 1.9 \mathrm{Ma}$, respectively. The number of confined tracks in samples from the $\mathrm{B}-\mathrm{B}^{\prime}$ profile is far too low to allow a reasonable statistical evaluation of the data. Mean track length in samples JS-9 and JS-11 are $10.61 \pm 2.53$ $(n=19)$ and $11.32 \pm 2.34(n=9) \mu \mathrm{m}$, respectively. $D_{\text {par }}$ values for these samples are in the range of 2.4 and $6.0 \mu \mathrm{m}$.

$(\mathrm{U}-\mathrm{Th}) / \mathrm{He}$ ages $(\mathrm{AHe})$ have been determined on apatites from two sandstone samples from profile B-B' (see Fig. 6 and Table 2). Sample JS-21 (Tera) yields AHe age of $31.1 \pm 1.5 \mathrm{Ma}$, and two splits of apatites from JS-12 (Oliván) of $39.8 \pm 2.8$ and $37.6 \pm 1.8 \mathrm{Ma}$.

\section{Thermal modelling}

Thermal modelling has been performed on samples MAO-3 and MAO-4 from the Oliván group in which track lengths associated with the two youngest age populations have been clearly separated. From the 
Table 1. Apatite and zircon fission-track age data from the Sierra de Cameros

\begin{tabular}{|c|c|c|c|c|c|c|c|c|c|c|c|}
\hline \multirow{2}{*}{$\begin{array}{l}\text { Sample No. } \\
\text { (mineral } \\
\text { type)* }\end{array}$} & \multirow{2}{*}{$\begin{array}{l}\text { Stratigraphic } \\
\text { age } \\
\text { Group }\end{array}$} & \multirow{2}{*}{$\begin{array}{l}\text { No. } \\
\text { of } \\
\text { grains }\end{array}$} & \multirow{2}{*}{$\begin{array}{l}\rho_{\mathrm{D}}^{\dagger}\left(10^{6}\right. \\
\left.\operatorname{trcm}^{-2}\right) \\
\left(N_{\mathrm{D}}\right)\end{array}$} & \multirow{2}{*}{$\begin{array}{l}\rho_{\mathrm{s}}\left(10^{6}\right. \\
\left.\operatorname{tr}^{-2}\right) \\
\left(N_{\mathrm{s}}\right)\end{array}$} & \multirow{2}{*}{$\begin{array}{l}\rho_{\mathrm{i}}\left(10^{6}\right. \\
\left.\operatorname{tr} \mathrm{cm}^{-2}\right) \\
\left(N_{\mathrm{i}}\right)\end{array}$} & \multirow{2}{*}{$\begin{array}{l}\text { Central age } \\
\pm 1 \sigma(\mathrm{Ma}) \\
P\left(\chi^{2}\right)\end{array}$} & \multirow{2}{*}{$\begin{array}{l}D_{\mathrm{par}}(\mu \mathrm{m}) / \mathrm{MTL} \\
\quad(\mu \mathrm{m}) \pm 1 \sigma\end{array}$} & \multicolumn{3}{|c|}{ Age populations $(\mathrm{Ma} \pm 1 \sigma), N_{\mathrm{f}}, W(\%)$} & \multirow{2}{*}{$\begin{array}{c}\text { Fit } \\
\text { statistics }\end{array}$} \\
\hline & & & & & & & & $\mathrm{P} 1$ & $\mathrm{P} 2$ & P3 & \\
\hline $\begin{array}{l}\text { MAO-3 } \\
\text { (Ap) }\end{array}$ & $\begin{array}{l}\text { Lower Albian } \\
\text { Oliván }\end{array}$ & 42 & $\begin{array}{l}1.132 \\
(5249)\end{array}$ & $\begin{array}{l}1.955 \\
(4995)\end{array}$ & $\begin{array}{l}5.269 \\
(13462)\end{array}$ & $\begin{array}{l}71.7 \pm 3.0 \\
0.00\end{array}$ & $\begin{array}{l}\mathrm{P} 1=1.4 \pm 0.1 / 12.8 \pm 2.2 \\
\mathrm{P} 2=1.4 \pm 0.1 / 11.7 \pm 2.4 \\
\mathrm{P} 3=1.3 \pm 0.4\end{array}$ & $\begin{array}{l}60.9 \pm 2.9 \\
N_{\mathrm{f}}=20.5 \\
W=13\end{array}$ & $\begin{array}{l}80.0 \pm 4.1 \\
N_{\mathrm{f}}=19.2 \\
W=12\end{array}$ & $\begin{array}{l}122.9 \pm 15.5 \\
N_{\mathrm{f}}=4.1 \\
W=18\end{array}$ & $\begin{array}{l}\chi^{2}=39 \\
l=37 \\
P(F)=0 \%\end{array}$ \\
\hline $\begin{array}{l}\text { MAO-3 } \\
(\mathrm{Zr})\end{array}$ & $\begin{array}{l}\text { Lower Albian } \\
\text { Oliván }\end{array}$ & 24 & $\begin{array}{l}0.394 \\
(1826)\end{array}$ & $\begin{array}{l}13.524 \\
(3511)\end{array}$ & $\begin{array}{l}1.7256 \\
(448)\end{array}$ & $\begin{array}{l}211.4 \pm 18.7 \\
0.04\end{array}$ & & $\begin{array}{l}184.9 \pm 13.4 \\
N_{\mathrm{f}}=19.4 \\
W=27\end{array}$ & $\begin{array}{l}419.6 \pm 82.7 \\
N_{\mathrm{f}}=4.6 \\
W=39\end{array}$ & & $\begin{array}{l}\chi^{2}=24 \\
l=21 \\
P(F)=0 \%\end{array}$ \\
\hline $\begin{array}{l}\text { JS-6 } \\
\text { (Ap) }\end{array}$ & $\begin{array}{l}\text { Lower Albian } \\
\text { Oliván }\end{array}$ & 74 & $\begin{array}{l}1.007 \\
(4669)\end{array}$ & $\begin{array}{l}1.547 \\
(5583)\end{array}$ & $\begin{array}{l}4.696 \\
(16948)\end{array}$ & $\begin{array}{l}58.0 \pm 3.4 \\
0.00\end{array}$ & $\begin{array}{l}\mathrm{P} 1=3.8 \pm 1 \\
\mathrm{P} 2=3.1 \pm 1 \\
\mathrm{P} 3=3.4 \pm 2\end{array}$ & $\begin{array}{l}45.2 \pm 2.8 \\
N_{\mathrm{f}}=45.1 \\
W=15\end{array}$ & $\begin{array}{l}57.8 \pm 6.0 \\
N_{\mathrm{f}}=24.4 \\
W=15\end{array}$ & $\begin{array}{l}123.2 \pm 14.9 \\
N_{\mathrm{f}}=3.5 \\
W=23\end{array}$ & $\begin{array}{l}\chi^{2}=74 \\
l=67 \\
P(F)=0 \%\end{array}$ \\
\hline $\begin{array}{l}\text { JS-8 } \\
(\mathrm{Ap})\end{array}$ & $\begin{array}{l}\text { Lower Albian } \\
\text { Oliván }\end{array}$ & 20 & $\begin{array}{l}1.124 \\
(5212)\end{array}$ & $\begin{array}{l}1.499 \\
(1041)\end{array}$ & $\begin{array}{l}5.053 \\
(3509)\end{array}$ & $\begin{array}{l}55.7 \pm 3.4 \\
0.07\end{array}$ & $\begin{array}{l}\mathrm{P} 1=4.5 \pm 3 \\
\mathrm{P} 2=2.6 \pm 1\end{array}$ & $\begin{array}{l}49.2 \pm 3.4 \\
N_{\mathrm{f}}=13.0 \\
W=18\end{array}$ & $\begin{array}{l}70.7 \pm 7.0 \\
N_{\mathrm{f}}=7.0 \\
W=19\end{array}$ & & $\begin{array}{l}\chi^{2}=23 \\
l=17 \\
P(F)=0 \%\end{array}$ \\
\hline $\begin{array}{l}\text { MAO-4 } \\
\text { (Ap) }\end{array}$ & $\begin{array}{l}\text { Lower Albian } \\
\text { Oliván }\end{array}$ & 46 & $\begin{array}{l}1.141 \\
(5289)\end{array}$ & $\begin{array}{l}1.503 \\
(3848)\end{array}$ & $\begin{array}{l}4.943 \\
(12655)\end{array}$ & $\begin{array}{l}59.1 \pm 2.4 \\
0.00\end{array}$ & $\begin{array}{l}\mathrm{P} 1=2.2 \pm 0.3 / 11.3 \pm 2.3 \\
\mathrm{P} 2=2.1 \pm 0.3 / 11.6 \pm 2.2 \\
\mathrm{P} 3=2.1 \pm 0.3\end{array}$ & $\begin{array}{l}54.3 \pm 2.4 \\
N_{\mathrm{f}}=32.5 \\
W=15\end{array}$ & $\begin{array}{l}69.8 \pm 5.6 \\
N_{\mathrm{f}}=12.5 \\
W=15\end{array}$ & $\begin{array}{l}127.3 \pm 24.7 \\
N_{\mathrm{f}}=1.0 \\
W=20\end{array}$ & $\begin{array}{l}\chi^{2}=42 \\
l=41 \\
P(F)=0 \%\end{array}$ \\
\hline $\begin{array}{l}\text { JS-9 } \\
\text { (Ap) }\end{array}$ & $\begin{array}{l}\text { Lower Albian } \\
\text { Oliván }\end{array}$ & 15 & $\begin{array}{l}0.929 \\
(4307)\end{array}$ & $\begin{array}{l}1.452 \\
(878)\end{array}$ & $\begin{array}{l}3.973 \\
(2402)\end{array}$ & $\begin{array}{l}55.6 \pm 3.2 \\
2.55\end{array}$ & $\mathrm{P} 1=2.4 \pm 0.4$ & & & & \\
\hline $\begin{array}{l}\text { JB-17 } \\
\text { (Ap) }\end{array}$ & $\begin{array}{l}\text { Lower Albian } \\
\text { Oliván }\end{array}$ & 23 & $\begin{array}{l}1.066 \\
(4942)\end{array}$ & $\begin{array}{l}1.220 \\
(663)\end{array}$ & $\begin{array}{l}3.532 \\
(1919)\end{array}$ & $\begin{array}{l}64.4 \pm 6.2 \\
0.00\end{array}$ & & $\begin{array}{l}21.4 \pm 5.1 \\
N_{\mathrm{f}}=2.4 \\
W=36\end{array}$ & $\begin{array}{l}60.0 \pm 4.1 \\
N_{\mathrm{f}}=15.1 \\
W=24\end{array}$ & $\begin{array}{l}105.6 \pm 12.6 \\
N_{\mathrm{f}}=5.5 \\
W=26\end{array}$ & $\begin{array}{l}\chi^{2}=25 \\
l=18 \\
P(F)=0 \%\end{array}$ \\
\hline $\begin{array}{l}\text { JS-11 } \\
\text { (Ap) }\end{array}$ & $\begin{array}{l}\text { Lower Albian } \\
\text { Oliván }\end{array}$ & 15 & $\begin{array}{l}0.883 \\
(4093)\end{array}$ & $\begin{array}{l}0.722 \\
(556)\end{array}$ & $\begin{array}{l}2.830 \\
(2179)\end{array}$ & $\begin{array}{l}34.5 \pm 1.9 \\
90.44\end{array}$ & $\mathrm{P} 1=6.0 \pm 1.4$ & & & & \\
\hline $\begin{array}{l}\text { JS-12 } \\
\text { (Ap) }\end{array}$ & $\begin{array}{l}\text { Lower Albian } \\
\text { Oliván }\end{array}$ & 61 & $\begin{array}{l}1.065 \\
(4941)\end{array}$ & $\begin{array}{l}1.163 \\
(4598)\end{array}$ & $\begin{array}{l}4.193 \\
(16578)\end{array}$ & $\begin{array}{l}48.5 \pm 2.3 \\
0.00\end{array}$ & $\begin{array}{l}\mathrm{P} 1=2.3 \pm 0.7 \\
\mathrm{P} 2=2.2 \pm 0.5\end{array}$ & $\begin{array}{l}41.9 \pm 1.6 \\
N_{\mathrm{f}}=43.3 \\
W=15\end{array}$ & $\begin{array}{l}62.7 \pm 3.6 \\
N_{\mathrm{f}}=16.7 \\
W=15\end{array}$ & & $\begin{array}{l}\chi^{2}=56 \\
l=56 \\
P(F)=0 \%\end{array}$ \\
\hline $\begin{array}{l}\text { JS-13 } \\
\text { (Ap) }\end{array}$ & $\begin{array}{l}\text { Apitan } \\
\text { Enciso }\end{array}$ & 35 & $\begin{array}{l}0.831 \\
(3855)\end{array}$ & $\begin{array}{l}1.065 \\
(1985)\end{array}$ & $\begin{array}{l}3.226 \\
(6015)\end{array}$ & $\begin{array}{l}46.5 \pm 2.7 \\
0.00\end{array}$ & $\begin{array}{l}\mathrm{P} 1=4.8 \pm 1.0 \\
\mathrm{P} 2=4.3 \pm 1.1\end{array}$ & $\begin{array}{l}40.8 \pm 1.7 \\
N_{\mathrm{f}}=30.6 \\
W=18\end{array}$ & $\begin{array}{l}88.6 \pm 12.7 \\
N_{\mathrm{f}}=4.4 \\
W=20\end{array}$ & & $\begin{array}{l}\chi^{2}=32 \\
l=32 \\
P(F)=0 \%\end{array}$ \\
\hline $\begin{array}{l}\text { JS-15 } \\
\text { (Ap) }\end{array}$ & $\begin{array}{l}\text { Hauterivian- } \\
\text { Barremian } \\
\text { Urbión }\end{array}$ & 22 & $\begin{array}{l}1.101 \\
(5102)\end{array}$ & $\begin{array}{l}0.931 \\
(747)\end{array}$ & $\begin{array}{l}3.486 \\
(2796)\end{array}$ & $\begin{array}{l}50.6 \pm 4.3 \\
0.00\end{array}$ & $\begin{array}{l}\mathrm{P} 1=4.7 \pm 1.1 \\
\mathrm{P} 2=4.7 \pm 1.5 \\
\mathrm{P} 3=4.0 \pm 0.1\end{array}$ & $\begin{array}{l}39.0 \pm 3.8 \\
N_{\mathrm{f}}=11.8 \\
W=24\end{array}$ & $\begin{array}{l}58.2 \pm 8.2 \\
N_{\mathrm{f}}=8.0 \\
W=21\end{array}$ & $\begin{array}{l}100.7 \pm 19.0 \\
N_{\mathrm{f}}=2.2 \\
W=23\end{array}$ & $\begin{array}{l}\chi^{2}=21 \\
l=17 \\
P(F)=2 \%\end{array}$ \\
\hline
\end{tabular}


Table 1. Continued

\begin{tabular}{|c|c|c|c|c|c|c|c|c|c|c|c|}
\hline \multirow{2}{*}{$\begin{array}{l}\text { Sample No. } \\
\text { (mineral } \\
\text { type)* }\end{array}$} & \multirow{2}{*}{$\begin{array}{l}\text { Stratigraphic } \\
\text { age } \\
\text { Group }\end{array}$} & \multirow{2}{*}{$\begin{array}{c}\text { No. } \\
\text { of } \\
\text { grains }\end{array}$} & \multirow{2}{*}{$\begin{array}{l}\rho_{\mathrm{D}}^{\dagger}\left(10^{6}\right. \\
\left.\operatorname{tr} \mathrm{cm}^{-2}\right) \\
\left(N_{\mathrm{D}}\right)\end{array}$} & \multirow{2}{*}{$\begin{array}{l}\rho_{\mathrm{s}}\left(10^{6}\right. \\
\left.\operatorname{tr~cm}^{-2}\right) \\
\left(N_{\mathrm{s}}\right)\end{array}$} & \multirow{2}{*}{$\begin{array}{l}\rho_{\mathrm{i}}\left(10^{6}\right. \\
\left.\operatorname{tr~cm}^{-2}\right) \\
\left(N_{\mathrm{i}}\right)\end{array}$} & \multirow{2}{*}{$\begin{array}{l}\text { Central age } \\
\pm 1 \sigma(\mathrm{Ma}) \\
P\left(\chi^{2}\right)\end{array}$} & \multirow{2}{*}{$\begin{array}{l}D_{\mathrm{par}}(\mu \mathrm{m}) / \mathrm{MTL} \\
\quad(\mu \mathrm{m}) \pm 1 \sigma\end{array}$} & \multicolumn{3}{|c|}{ Age populations $(\mathrm{Ma} \pm 1 \sigma), N_{\mathrm{f}}, W(\%)$} & \multirow{2}{*}{$\begin{array}{c}\text { Fit } \\
\text { statistics }\end{array}$} \\
\hline & & & & & & & & $\mathrm{P} 1$ & $\mathrm{P} 2$ & P3 & \\
\hline $\begin{array}{l}\text { POC-9 } \\
\text { (Ap) }\end{array}$ & $\begin{array}{l}\text { Hauterivian- } \\
\text { Barremian } \\
\text { Urbión }\end{array}$ & 25 & $\begin{array}{l}1.168 \\
(5417)\end{array}$ & $\begin{array}{l}0.270 \\
(202)\end{array}$ & $\begin{array}{l}1.099 \\
(822)\end{array}$ & $\begin{array}{l}48.3 \pm 4.1 \\
82.61\end{array}$ & & & & & \\
\hline $\begin{array}{l}\text { POC-9 } \\
\text { (Zr) }\end{array}$ & $\begin{array}{l}\text { Hauterivian- } \\
\text { Barremian } \\
\text { Urbión }\end{array}$ & 20 & $\begin{array}{l}0.3854 \\
(1787)\end{array}$ & $\begin{array}{l}9.3645 \\
(1615)\end{array}$ & $\begin{array}{l}2.9108 \\
(502)\end{array}$ & $\begin{array}{l}84.7 \pm 5.5 \\
65.73\end{array}$ & & & & & \\
\hline $\begin{array}{l}\text { JS-21 } \\
\text { (Ap) }\end{array}$ & $\begin{array}{l}\text { Tithonian } \\
\text { Tera }\end{array}$ & 21 & $\begin{array}{l}0.863 \\
(4001)\end{array}$ & $\begin{array}{l}1.322 \\
(1347)\end{array}$ & $\begin{array}{l}6.139 \\
(6256)\end{array}$ & $\begin{array}{l}28.7 \pm 1.5 \\
0.13\end{array}$ & $\begin{array}{l}\mathrm{P} 1=3.2 \pm 0.3 \\
\mathrm{P} 2=3.2 \pm 0.3\end{array}$ & $\begin{array}{l}25.5 \pm 1.8 \\
N_{\mathrm{f}}=13.1 \\
W=17\end{array}$ & $\begin{array}{l}34.6 \pm 2.9 \\
N_{\mathrm{f}}=7.9 \\
W=15\end{array}$ & & $\begin{array}{l}\chi^{2}=19 \\
l=18 \\
P(F)=0 \%\end{array}$ \\
\hline
\end{tabular}

*Ap, apatite; $\mathrm{Zr}$, zircon.

${ }^{\dagger} \mathrm{CN}-5$ for apatites and $\mathrm{CN}-2$ for zircons.

Samples MAO-3, MAO-4 and POC-9 measured by Luis Barbero $\zeta(\mathrm{CN}-5)=337.8 \pm 5.2$ and $\zeta(\mathrm{CN}-2)=137.5 \pm 4.5$.

All samples JS measured by Pedro del Rio $\zeta(\mathrm{CN}-5)=339.2 \pm 8.2$.

$\rho_{\mathrm{D}}$, glass monitor track density; $\rho_{\mathrm{s}}$, spontaneous track density; $\rho_{\mathrm{i}}$, induced track density; $N_{\mathrm{D}, \mathrm{s}, \mathrm{i}}$, number of tracks counted to determinate the reported track density.

$N_{\mathrm{f}}$, number of grains in age population; $W$, relative standard deviation; $\chi^{2}$, goodness of fit parameter; 1 , degrees of fredoom; $P(F)$, probability that the random variation alone could produce the observed $F$ value for peak 2 or 3 .

MTL, mean track length. 


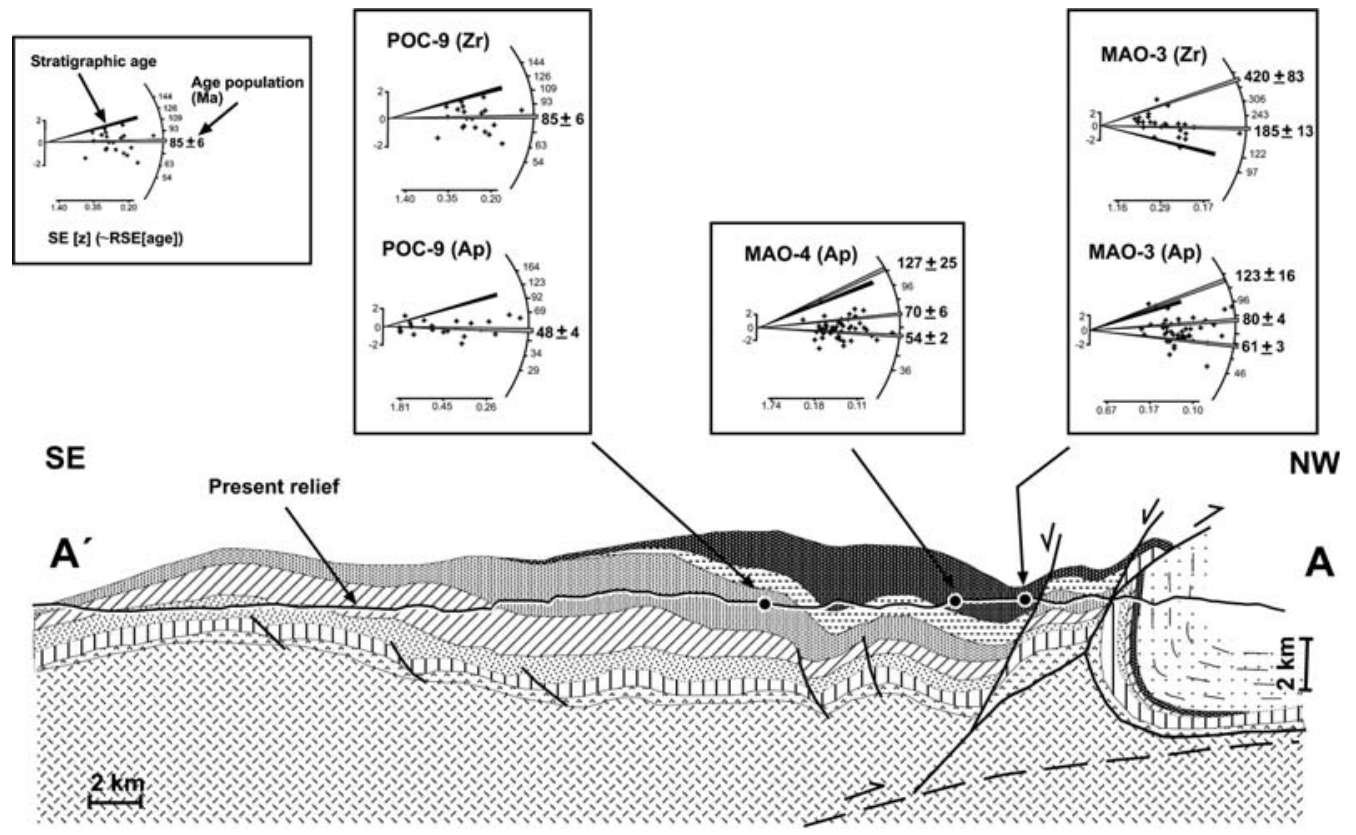

Fig. 3. Cross-section along $A-A^{\prime}$ (see Fig. 1 for the location and legend) modified after Gil-Imaz (2001), showing the location of the samples and AFT and ZFT radial plots.

analysis of the age population distribution in these two samples, it is clear that both have undergone partial resetting after deposition. Both populations retain an inherited thermal signal from the source areas. Constraints used for modelling include: (1) the depositional age of the sediment (Lower Albian); (2) the fact that the AFT system is not fully reset indicates that maximum temperatures reached after deposition should be less than approximately $120{ }^{\circ} \mathrm{C}$ (in agreement with the stratigraphic position of these two samples from the Oliván group); and (3) for the predepositional history a free temperature constraint has been used for times in the 280-120 Ma interval. The chlorine content of these two samples is similar to the Durango apatite, therefore the Laslett et al. (1987) annealing model has been used. Modelling was performed using the AFTSolve program (Ketcham et al. 2000). Results from modelling indicate that: (1) the post-depositional history is similar in both samples, showing that a fast heating period soon after deposition was followed by continuous cooling from maximum palaeotemperatures of $110^{\circ} \mathrm{C}$ at $108-80 \mathrm{Ma}$ to the present day (which is consistent with the timing of the low-grade metamorphic event of the area); and (2) a pre-Albian inherited history is poorly constrained by modelling.

\section{Discussion}

The single ZFT age component that is younger than the depositional age in sample POC-9 (top of the Urbión group) indicates that, at least in the eastern part of the basin (profile $\mathrm{A}-\mathrm{A}^{\prime}$ ), temperatures above $300-350{ }^{\circ} \mathrm{C}$ were reached (Yamada et al. 1995; Tagami et al. 1998), probably during the low-grade metamorphic event (108-86 Ma: Casquet et al. 1992). However, the two old age populations of samples MAO-3 and MAO-4 indicate that the Oliván group sediments were only partially reset. The vertical distance between samples POC-9 and MAO-3, according to the vertical stacking model of Casas-Sainz \& Gil-Imaz (1998), can be easily deduced by adding the sedimentary thickness for the Oliván and Enciso groups, and is about $2.8 \mathrm{~km}$. The difference in palaeotemperature between these two samples, on the basis of the apatite and zircon fission-track data (ZFT closure temperature of $350{ }^{\circ} \mathrm{C}$ : Tagami et al. 1998) and an AFT closure temperature of $110{ }^{\circ} \mathrm{C}$ (Green et al. 1989), is estimated to be around $240{ }^{\circ} \mathrm{C}$ (ZFT ages are clearly reset in sample POC-9 but not in sample MAO-3). The palaeogeothermal gradient calculated with these data is close to $86{ }^{\circ} \mathrm{C} \mathrm{km}^{-1}$. Based on low-grade metamorphic parageneses, Mata et al. (2001) 

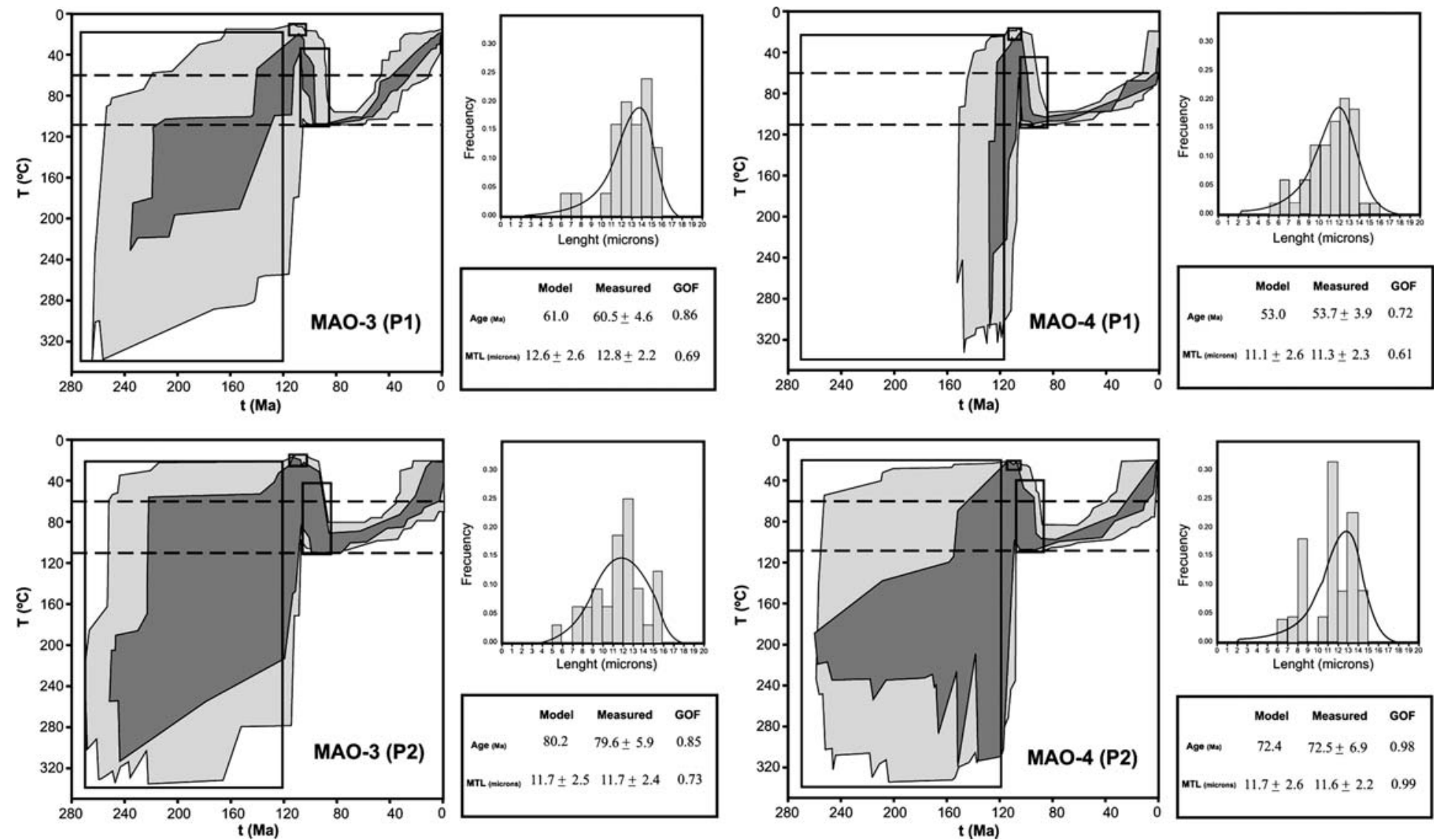

Fig. 4. Thermal models and mean track-length distribution for samples MAO-3 (left) and MAO-4 (right) for the AFT age populations P1 (up) and P2 (down). The dashed lines correspond to partial annealing zone boundaries for AFT. The T-t path envelopes are plotted. The light grey area includes the acceptable paths, and the dark grey area includes the good paths. The constraints are shown as boxes (explanation is in the text). 
(a)

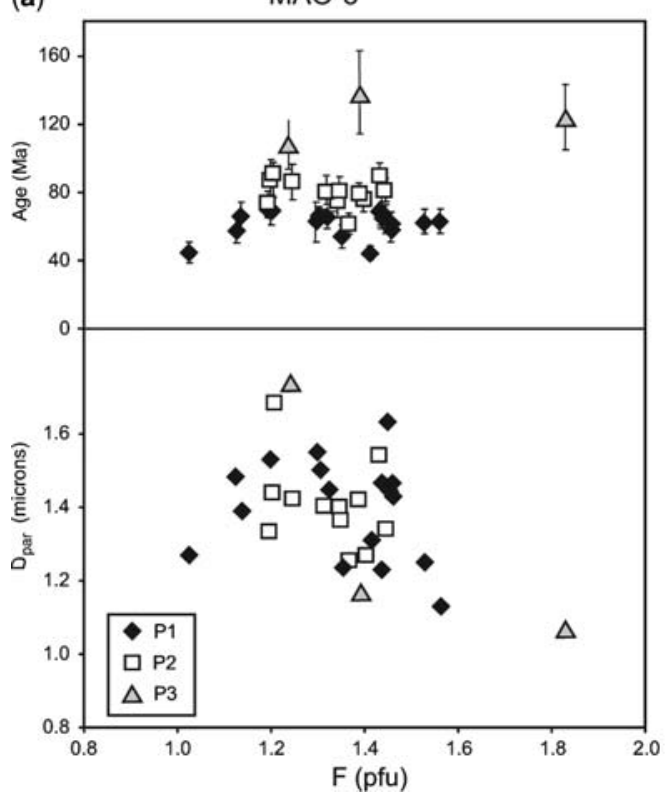

(b)

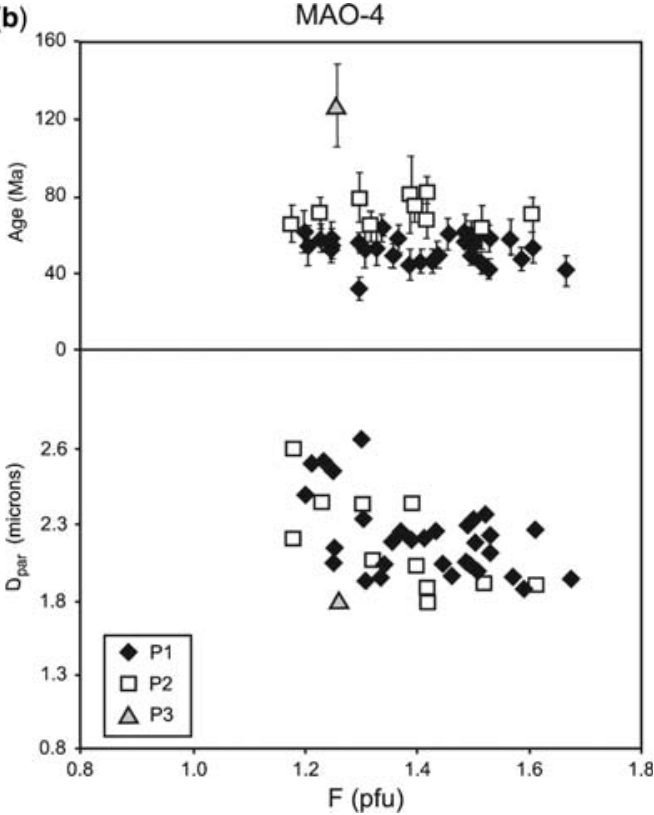

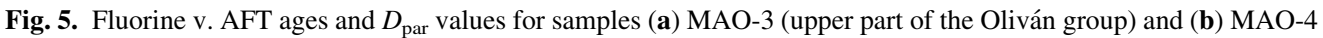
(lower part of the Oliván group).

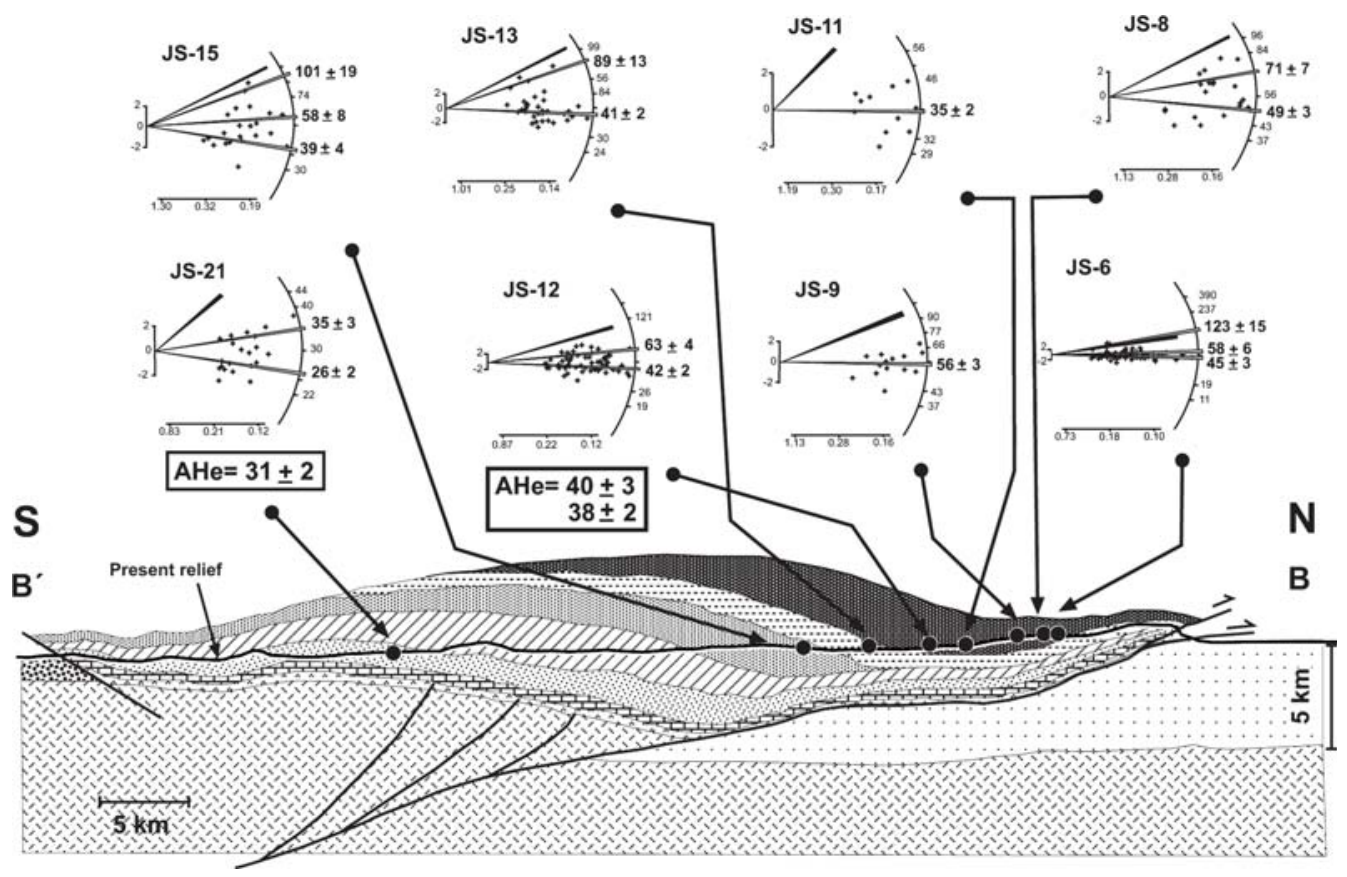

Fig. 6. Cross-section along $B^{\prime}-B$ (see Fig. 2 for the location and legend) (structural interpretation from Casas-Sainz \& Gil-Imaz 1998, p. 812, fig. 8A) showing the location of the samples and the radial plots for AFT and AHe ages. 


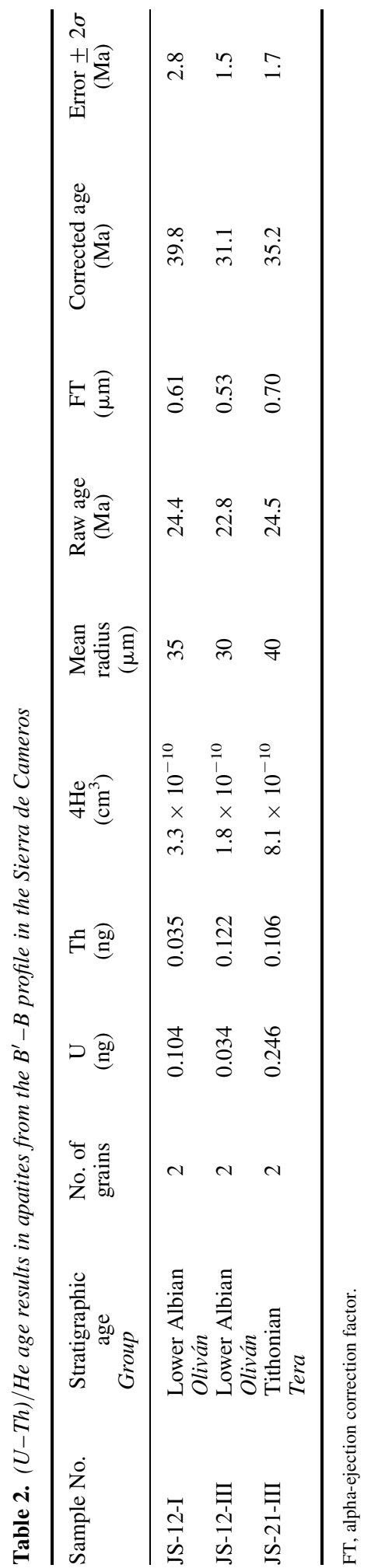

calculated a similarly high maximum palaeogeothermal gradient of approximately $70{ }^{\circ} \mathrm{C} \mathrm{km}^{-1}$ at the end of the extensional stage. Temperatures obtained in samples located within the Urbión group can be attained in the basin depocentre if we consider a tectonic model of vertical superposition of the sedimentary units with a high geothermal gradient. When considering the alternative model of lateral stacking of sedimentary units (Mas et al. 2002), the deepest part of the basin cropping out at present (the base of the Urbión group) would only be covered by a maximum sedimentary thickness of $2 \mathrm{~km}$ (Mata et al. 2001). This implies that a geothermal gradient of more than $150{ }^{\circ} \mathrm{C} \mathrm{km}^{-1}$ is necessary to explain the high temperatures reached in the Urbión group. Therefore, the sag basin model of Mas et al. (1993) and Guimerà et al. (1995) requires a geothermal gradient of at least $150{ }^{\circ} \mathrm{C} \mathrm{km}^{-1}$ that, on the basis of the FT and fluid inclusion data and in the absence of magmatism or a hydrothermal fluid activity, seems unrealistic (Casquet et al. 1992). Furthermore, other arguments against this hypothesis come from the source-sediment balance, because if we compare the volume of sediments deposited in the Ebro foreland basin eroded from the Sierra de Cameros it is possible to estimate that the amount of removed material from the Cameros Basin cannot be balanced with a tectonic model which proposes a maximum thickness of eroded sediments of $2 \mathrm{~km}$ (see e.g. Muñoz-Jiménez \& Casas-Sainz 1997).

AFT data from all samples from profile $\mathrm{A}-\mathrm{A}^{\prime}$ and $\mathrm{B}-\mathrm{B}^{\prime}$ (except JS-6) show cooling ages younger than their depositional age and record the time of cooling from more than $110{ }^{\circ} \mathrm{C}$. However, AFT age populations range from 21 to $124 \mathrm{Ma}$. The presence of several age components in samples with evidence of total resetting of the fission tracks in apatite (for example, the presence of chloritoid in the mineral paragenesis) could be explained by differences in chemical composition of the apatites, which produces different kinetic behaviour during annealing (Green et al. 1986; Ketcham et al. 1999). A study of $D_{\mathrm{par}}$ and the chemical composition of apatites in these samples is underway to shed more light on the origin of the dispersion of the results.

The youngest age components of the AFT data from the $\mathrm{B}-\mathrm{B}^{\prime}$ profile (Fig. 7a) record a first cooling event at $45-55 \mathrm{Ma}$ in the northern part of the Cameros Basin, close to the present-day thrust front (as seen in samples JS-6, JS-8 and JS-9). The second, more important, cooling event is recorded by samples JS-11-JS-15 (see Fig. 7) at 30$40 \mathrm{Ma}$. This coincides with an important period of tectonic activity, with a horizontal displacement 
(a)

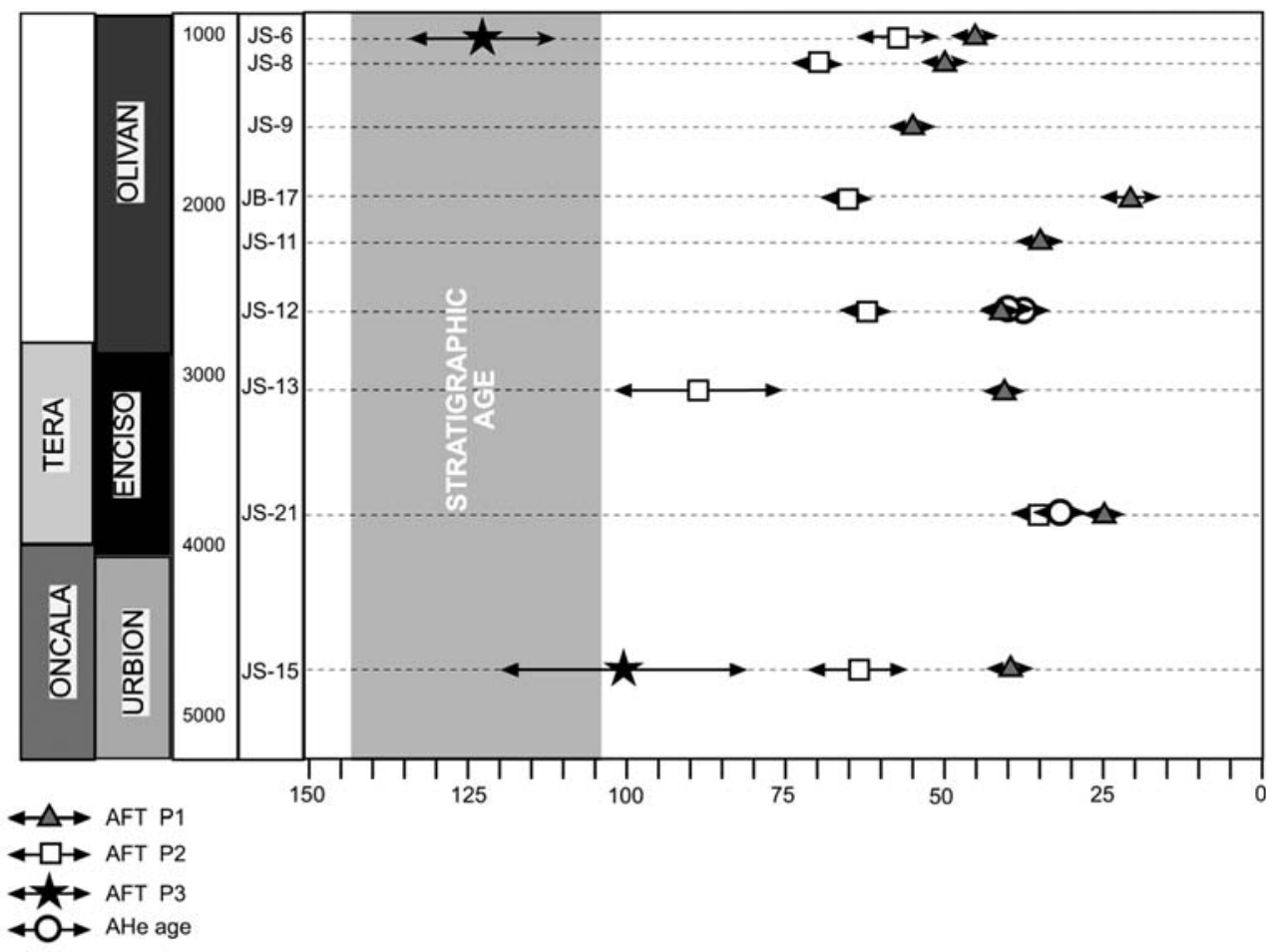

(b)

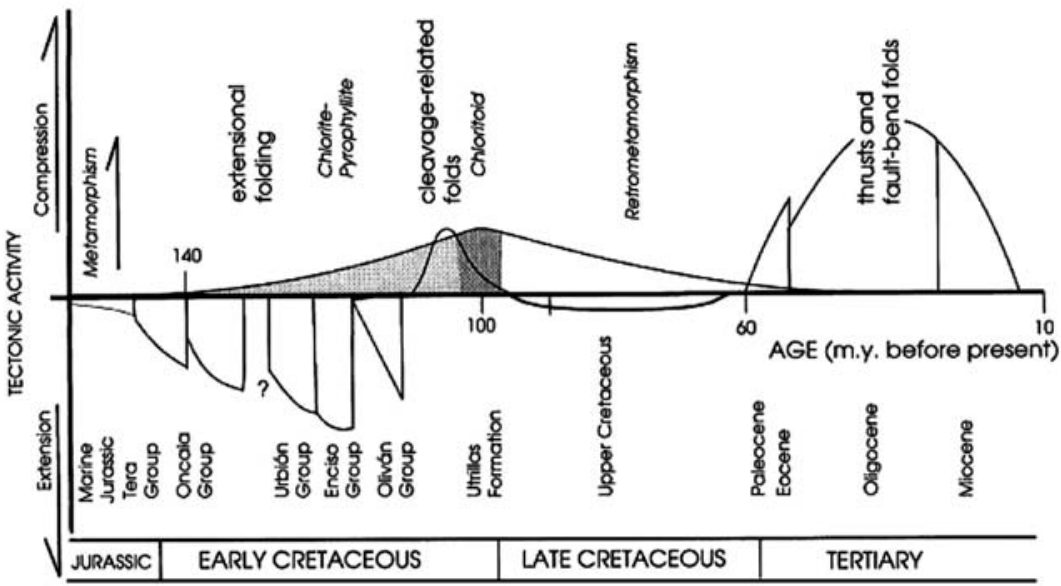

Fig. 7. (a) AFT age populations and AHe cooling ages v. the estimated depth of the samples at the time of deposition from samples along the $\mathrm{B}^{\prime}-\mathrm{B}$ profile. (b) The main thermal events that occurred in the Cameros Basin (Casas-Sainz \& Gil-Imaz 1998, p. 814, fig. 9B).

velocity of the thrusts of 0.8 and $1.25 \mathrm{~mm}$ year $^{-1}$ for the central and eastern part of the basin, respectively (Muñoz-Jiménez \& Casas-Sainz 1997), and so we consider that this age can constrain the age of the main pulse of tectonic inversion in the area. The AHe ages of JS-12 and JS-21 are similar to the youngest apatite fission-track age component in these samples (Fig. 7a), consistent with rapid cooling through the apatite partial annealing zone (PAZ; from 110 to $60^{\circ} \mathrm{C}$ ) to the $\mathrm{AHe}$ closure temperature $\left(60-70{ }^{\circ} \mathrm{C}\right.$ : Farley 2000$)$.

The cooling rate can be determined by combining the AFT and ZFT data. For sample POC-9, in the eastern part of the Urbion group, is around 
5.4-8.9 ${ }^{\circ} \mathrm{C} \mathrm{Ma}^{-1}$. These rates indicate that the basin cooled rapidly between 85 and $48 \mathrm{Ma}$. The modelled thermal histories for samples MAO-3 and MAO-4 from the upper and lower parts of the Olivan group show a fast heating during the metamorphic event, up to $100{ }^{\circ} \mathrm{C}$, of about 5$8{ }^{\circ} \mathrm{C} \mathrm{Ma}^{-1}$. A continuous regional cooling of around $0.6-1.6^{\circ} \mathrm{C} \mathrm{Ma}^{-1}$ is observed from the thermal peak (c. $100 \mathrm{Ma})$ to present. This is consistent with the progressive exhumation of the Cameros Basin during the Tertiary that resulted in the accumulation of approximately $5 \mathrm{~km}$ of Tertiary sediments in the western part of Ebro Basin, the Rioja Trough, which represents the foreland basin of the Sierra de Cameros (Muñoz-Jiménez \& Casas Sainz 1997).

\section{Conclusions}

The Sierra de Cameros was an intracratonic sedimentary basin filled by continental synrift sediments during the lower Cretaceous. During the extensional stage, the sedimentary fill attained temperatures of more than $110{ }^{\circ} \mathrm{C}$, as demonstrated by the young AFT ages of all samples except those of the uppermost Olivan group sediments. Temperatures above $300{ }^{\circ} \mathrm{C}$ were reached in the Urbión group, as revealed by the young ZFT age of sample POC-9. This is consistent with the low-grade metamorphism observed in the central part of the basin. From an independent estimate of the palaeogeothermal gradient $\left(86^{\circ} \mathrm{C} \mathrm{km}^{-1}\right)$, a sediment thickness of $8 \mathrm{~km}$ is necessary to explain these temperatures and the sediment volume found in the Ebro foreland basin. These data suggest that a model of vertical sediment accumulation is more feasible than the lateral stacking model. Alpine compression produced the tectonic inversion of the basin during the Tertiary. Combining ZFT and AFT data, we calculated that between 85 and $48 \mathrm{Ma}$ rocks from the Urbión group were cooled at a rate of $5.4-8.9^{\circ} \mathrm{C} \mathrm{Ma}^{-1}$. An increase in the cooling rate is identified by the coincidence of the youngest age component of AFT results and the AHe cooling ages, at about $40 \mathrm{Ma}$. This represents the time of maximum uplift and cooling, which produced the exhumation of the main part of the basin related to the Alpine orogenesis.

We thank B. Ventura and two anonymous reviewers for the helpful comments made to a previous version of this manuscript. This work has been supported by MCYT project BTE2002-04168-C03-02 and by the Consolider-Ingenio 2010 Programme under project CSD2006-0041 'TopoIberia'. This research is part of the objectives of the Junta de Andalucía PAI group RNM-160. We thank D. Vilbert and J. Foeken for assistance at SUERC. The SUERC He laboratory is supported by the Scottish Universities.

\section{Appendix}

\section{Analytical methods}

Thirteen samples of sandstones were collected along two cross-sections (north-south and NE-SW) perpendicular to the strike of regional structures. Mineral separations were carried out using standard methods. In this work we use the $\zeta$ approach for fission-track analyses of individual apatite and zircon crystals (Hurford \& Green 1983). Apatites and zircons were mounted in U-free epoxy resin and in a piece of Teflon, respectively, and polished with 1 and $3 \mu \mathrm{m}$ diamond and $0.25 \mu \mathrm{m}$ aluminium oxide. To reveal the spontaneous tracks, the apatite crystals were etched in $5 \mathrm{M} \mathrm{HNO}_{3}$ for $20 \pm 1 \mathrm{~s}$. The zircons were prepared according to the procedure described by Naeser et al. (1987). Three replicates for each sample were etched with a low-melting-point binary eutectic of $\mathrm{NaOH}$ and $\mathrm{KOH}$ at $239^{\circ} \mathrm{C}$ for a period of between 6 and $100 \mathrm{~h}$ to ensure all of the zircon was adequately etched.

We applied the external detector method using thin U-free muscovite sheets as detectors. We used two dosimeters at the top and bottom of the irradiation capsule to determine the flux of thermal neutrons' irradiation; $\mathrm{CN}-5$ and $\mathrm{CN}-2$ for apatite and zircon, respectively. The irradiation was performed at HIFAR (Australia). The neutron fluence was $9 \times 10^{15}$ and $1 \times 10^{15} \mathrm{n} \mathrm{cm}^{-2}$ for apatites and zircons, respectively. All of the irradiated mica sheets were etched in $5 \mathrm{M} \mathrm{HF}$ at room temperature for $40 \mathrm{~min}$. For track counting and length measurements, a magnification of $1250 \times$ was used.

The best-fit binomial peak-fitting routine of Galbraith \& Green (1990) was used to deconvolve the fission-track grain-age spectra in samples containing more than one age population. Calculations were performed using the Windows version of the BINOMFIT program of Brandon (1992, 1996). The procedures were based on the maximum-likelihood method, where the best-fit solution is determined by comparing the age distribution of the data to a predicted mixed binomial distribution.

Apatite grains for $(\mathrm{U}-\mathrm{Th}) / \mathrm{He}$ age determinations were hand-picked using a stereographic binocular microscope $(220 \times$ magnification). Only grains with good crystal shape and no mineral inclusions were selected. Two crystals per sample were packed in Pt foil tubes and loaded in batches of 40 into an ultra-high vacuum extraction cell. Helium was extracted by heating the foil with an $808 \mathrm{~nm}$ diode laser to approximately $1000{ }^{\circ} \mathrm{C}$. After a short clean-up step, helium was measured using a Hiden HAL3F gas source quadrupole mass spectrometer following the procedures of Foeken et al. (2006). Samples were then diluted in $5 \% \mathrm{HNO}_{3}$ and spiked with ${ }^{230} \mathrm{Th}$ and ${ }^{235} \mathrm{U}$, and the $\mathrm{U}$ and $\mathrm{Th}$ concentrations measured using a VG PQ2.5 inductively coupled plasma mass spectrometer (Balestrieri et al. 2005). Ages were corrected for alpha-recoil using the procedure of Farley et al. (1996).

Apatite compositions were measured by electron microprobe (Jeol Superprobe JXA-8900-M) using operating conditions of $15 \mathrm{kV}, 20 \mathrm{nA}$ and a beam diameter of 
2-5 $\mu \mathrm{m}$, and a ZAF (atomic number (Z), absorption (A) and fluorescence $(F))$ correction procedure.

\section{References}

Balestrieri, M. L., Stuart, F. M., Persano, C., AвbAte, E. \& BIgAZZI, G. 2005. Geomorphic development of the scarpment of the Eritrean margin, southern Red Sea from combined apatite fission track and (U-Th)/He thermochronometry. Earth and Planetary Science Letters, 231, 97-110.

BRANDON, M. T. 1992. Decomposition of fission-track grain-age distributions. American Journal of Science, 292, 535-564.

BRANDON, M. T. 1996. Probability density plot for fission-track grain-age samples. Radiation Measurements, 26, 663-676.

CASAS-SAinZ, A. M. \& GIL-IMAZ, A. 1998. Extensional subsidence, contractional folding and thrust inversion of the Estern Cameros Massif, northern Spain. Geological Rundschau, 86, 802-818.

Casquet, A., Galindo, C. ET AL. 1992. El metamorfismo en la cuenca de los Cameros, Geocronología e implicaciones tectónicas. Geogaceta, 11, 22-25.

FARLEY, K. A. 2000. Helium diffusion from apatite: general behavior as illustrated by Durango fluorapatite. Journal of Geophysical Research, 105, 2903-2914.

FARley, K. A., Wolf, R. A. \& Silver, L. T. 1996. The effects of long alpha-stopping distances on (U-Th)/He ages. Geochimica et Cosmochimica Acta, 60, 4223-4229.

Foeken, J. P. T., Stuart, F. M., Dobson, K. J., Persano, C. \& Vilbert, D. 2006. A diode laser system for heating minerals for $(\mathrm{U}-\mathrm{Th}) / \mathrm{He}$ chronometry. Geochemistry, Geophysics, Geosystems, 7, 1-9, Q04015, doi:10.1029/2005GC001190.

Galbraith, R. F. \& GReEN, P. F. 1990. Estimating the component ages in a finite mixture. Nuclear Tracks and Radiation Measurements, 17, 197-206.

Gil-ImaZ, A. 2001. La Estructura de la Sierra de Cameros: Deformación dúctil y su Significado a Escala Cortical. PhD thesis. Instituto de Estudios Riojanos, Colección Ciencias de la Tierra, 23, 305.

Gil-Imaz, A., Pocoví, A., Lago, M. \& Parés, J. M. 2000. Effect of lithostatic pressure and tectonic deformation on the magnetic fabric (anisotropy of magnetic susceptibility) in low-grade metamorphic rocks. Journal of Geophysical Research, 105, 305-317.

Gil-Imaz, A., Villalain, J. J., Barbero, L., GonzaLEZ, G., MATA, P. \& CASAS, A. M. 2002. Aplicación de técnicas geoquímicas, geofísicas y mineralógicas al estudio de la cuenca de Cameros. Implicaciones geométricas y evolutivas. Zubía, Instituto de Estudios Riojanos, 14, 65-98.

Goldberg, J. M., Guiraud, M., Maluski, H. \& SÉGURET, M. 1988. Caractères pétrologiques et âge du métamorphisme en contexte distensif du basin sur décrochement de Soria (Crétacéinférieur, Nord Espagne). Les Comptes Rendus de ĺ Académie des Sciences, Paris, 307, 521-527.

Green, P. F., Duddy, I. R., Gleadow, A. J. W., Tingate, P. R. \& Laslett, G. M. 1986. Thermal annealing of fission tracks in apatite: 1 . A qualitative description. Chemical Geology (Isotope Geosciences Section), 59, 237-253.

Green, P. F., Duddy, I.R, Laslett, G. M., Hegarty, K. A., Gleadow, A. J. W. \& Lovering, J. F. 1989. Thermal annealing of fission tracks in apatite: 4. A quantitative modelling techniques and extension to geological timescales. Chemical Geology (Isotope Geosciences Section), 79, 155-182.

Guimerà, J., Alonso, A. \& MAS, J. R. 1995. Inversion of an extensional-ramp basin by a newly formed thrust: the Cameros basin (N Spain). In: BUCHANAN, J. G. \& Buchanan, P. G. (eds) Basin Inversion. Geological Society, London, Special Publications, 88, 433-453.

GuIRAUD, M. 1983. Evolution Tectono-sedimentarie du Basin Wealdien (Crétacé inferieur) en relais de Décrochements de Logroño-Soria ( $N$-W Espagne). $\mathrm{PhD}$ thesis, Languedoc, 1-186.

GUIRAUD, M. \& SÉGURET, M. , 1984. Releasing solitary overstep model for the Late Jurassic-Early Creataceous (Wealdian) Soria strike-slip basin (North Spain). In: BIDdle, K. T. \& Christie-Blick, N. (eds) Strike-slip Deformation, Basin Formation and Sedimentation. SEPM, Special Publications, 37, 159-175.

Hurford, A. \& GREEN, P. F. 1983. The zeta calibration of fission-track dating. Chemical Geology, 1, 285-317.

Ketcham, R. A., Donelick, R. A. \& Carlson, W. D. 1999. Variability of apatite fission track annealing kinetics III: extrapolation to geological time scale. American Mineralogist, 84, 1235-1255.

Ketcham, R. A., Donelick, R. A. \& Donelick, M. B. 2000. AFTSolve: a program for multi-kinetic modeling of apatite fission-track data. Geological Materials Research, 2, 32.

Laslett, G. M., Green, P. F., Duddy, I. R. \& GLEADOW, A. J. W. 1987. Thermal annealing of fission tracks in apatite: 2. A quantitative analysis. Chemical Geology (Isotope Geosciences Section), 65, $1-13$.

Martín I Closas, C. 1989. Els carófits del Cretacé inferior de les Conques perifériques del Bloc de $L$ Ebre. $\mathrm{PhD}$ thesis, Universidad de Barcelona.

Mas, J. R., Alonso, A. \& Guimerà, J. 1993. Evolución tectonosedimentaria de una cuenca extensional intraplaca: la cuenca finijurásica-eocretácica de los Cameros (La Rioja-Soria). Revista de la Sociedad Geológica de España, 6, 129-144.

Mas, J. R., Alonso, A. \& Guimerà, J. 1994. Réplica del artículo: Evolución tectonosedimentaria de una cuenca extensional intraplaca: la cuenca finijurásicaeocretácica de los Cameros (La Rioja-Soria). Revista de la Sociedad Geológica de España, 7, 347-355.

MAs, R. \& SEgura, M. ET AL. 2002. The Iberian Basin. In: Gibbons, W. \& Moreno, T. (eds) The Geology of Spain. Geological Society, London, 284-292.

Mata, M. P., OSÁCAR, M. C. \& LÓPEZ-Aguayo, F. 2000. Una aproximación al área fuente del Weald de Cameros: datos geoquímicos. Geotemas, 1, (3) $263-265$.

Mata, M. P., Casas, A. M., Canals, A., Gil, A. \& Pocovi, A. 2001. Thermal history during Mesozoic extension and Tertiary uplift in the Cameros Basin, northern Spain. Basin Research, 13, 91-111.

Muñoz, A., Soria, A., Canudo, J. I., Casas, A., Gil-IMAZ, A. \& MATA, M. P. 1997. Caracterización 
estratigráfica y sedimentológica del Albiense marino del borde Norte de la Sierra de Cameros. Implicaciones paleogeográficas. Cuadernos de Geología Hispánica, 21-22, 427-435.

Muñoz-JimÉnez, A. \& CASAs-SAinz, A. M. 1997. The Rioja trough: tectono-sedimentary evolution of a foreland symmetric basin. Basin Research, 9, 65-85.

Naeser, N. D., Zeitler, P. K., Naeser, C. W. \& CERveny, P. F. 1987. Provenience studies by fission track dating of zircon - Etching and counting procedures. Nuclear Tracks and Radiation Measurements, 13, $121-126$.

SCHUDACK, M. 1987. Charophytenflora und fazielle Entwicklung der Grenzschichten mariner Jura/ Wealden in der Nordwestlichen Iberischen Ketten (mit Vergleichen zu Asturien und Kantabrien). Paleontographica Abteilung B, 204, 108.

Tagami, T., Galbraith, R. F., Yamada, R. \& LASLETT, G. M. 1998. Revised annealing kinetics of fission tracks in zircon and geological implications. In: VAN DEN Haute, P. \& DE Corte, F. (eds) Advances in Fission-Track Geochronology, Volume 10. Kluwer, Dordrecht, 99-112.

Tischer, G. 1966. El delta Weáldico de las montañas Ibéricas Occidentales y sus enlaces tectónicos. Notas y Comunicaciones Instituto Geológico y Minero de España, 81, 53-78.

YAmAda, R., TAGAmi, T., NishimURA, S. \& Ito, H. 1995. Annealing kinetics of fission track in zircon: an experimental study. Chemical Geology, 122, 249-258. 